\title{
Anne Booth
}

Economic Change in Modern Indonesia: Colonial and Post-colonial Comparisons.

Cambridge: Cambridge University Press, 2016, x + 261 pp. ISBN 9781107521391,

price: GBP 19.99 (paperback).

Even to the most jaded students of the Indonesian economy, Anne Booth manages to reveal new, and sometimes surprising, insights in Economic Change in Modern Indonesia. Anyone interested in the contemporary Indonesian economy will be much better informed by reading it and learning about the legacy of colonialism in shaping institutions that affect Indonesia's contemporary economic outlook. Booth argues that despite some remarkable economic progress in Indonesia since 1950, several economic development issues dating back to the Dutch colonial period remain unresolved; namely, the unholy alliance between the government and private sectors, the efficacy of 'populist' government policies to reduce poverty and inequality, and the limited ability of the government to finance development.

How colonization and colonial government policies have persistent effects on economic performance of independent countries is not a new topic for economists. For example, in the field of macroeconomics, it is well-established that different types of colonialism led to different institutional settings, resulting in different long-run growth trajectories post-independence. Numerous applied microeconomics studies quantitatively estimate the effect of colonial government policies, such as the building of railways or sugar plantation development, on their current economic activities' outcomes, such as trade cost, real income, or production-enhancing institutions.

What Professor Booth does in this book, however, is to go deep into one country-specific case and provide us with a rich economic history analysis to support her main argument: some institutional rigidities from the colonial era continue to assert their influence despite 70 years of post-independence economic and political ups and downs. Economists working on the Indonesian economy, as well as political scientists and public policy specialists, will find this book a valuable complement to their quantitative modeling or econometric results, providing deeper insights and a broader context than can be found in scholarship limited to econometric modelling. Students working on privatization and deregulation, income redistribution policies, and fiscal policies in Indonesia may find themselves surprised by the fact that many of current institutional constraints for economic reform can be traced all the way back to the late Dutch colonial period, as Booth emphasizes.

A large part of this book, chapters 2 to 6 , exhibits a historical overview of the modern Indonesian economy, divided over three historical watersheds:

(C) AKHMAD RIZAL SHIDIQ, 2018 | DOI:10.1163/22134379-17402004

This is an open access article distributed under the terms of the prevailing CC-BY-NC license 
Indonesia's Independence Day, the rise of New Order regime in 1966, and the 1997-1998 financial crisis. These chapters are equipped with a considerable amount of descriptive statistics of major micro and macro-economic indicators, to point out that the accounting for Indonesian economic achievement and failures is never a straightforward exercise and, in many ways, open to equally credible different interpretations. Yet, in my opinion, the most valuable takeaway from these chapters is not those statistics per se, but Booth's assessment of the political economy dynamic that motivates the changes of such economic indicators. For example, it would be misguided to read the declining share of government share of total investment expenditures in the 199os as a sign for the retreat of the state from the economy, because it turned out that a substantial amount of off-budget funds was now being used to finance stateenterprise projects closely related to Soeharto associates (p. 208). Booth also expertly maps and illustrates the interplay among various interest groups and key political actors, for example, between economic rationalist and nationalist camps, in pressing for a change in policy direction in response to exogenous shocks to the economy.

I found the discussion on the late-colonial and 1950s periods particularly interesting. Booth emphatically points out that, contrary to what many commentators believe, these periods usually characterized as economically disastrous have in fact seen some positive developments and progress. The chapters on the New Order and 1998 crisis-period, while informative, seems to be of less value-added, simply because there have already been voluminous research works in circulation on the same topic with more or less similar messages. On the other hand, the chapter on Susilo Bambang Yudhoyono's presidency from 2004 to 2014 would have been more informative if it had gone beyond accounting for the successes and failures of the regime to discuss the calculus to the political economy regarding his major administration policies, which were conducted in a new liberal democracy context that the country has never experienced since the 195 os.

Indeed, an extensive evaluation of the 70 years of economic development in a country, as this book provides, is very complex and, inevitably, has some loose ends. Part of the problem is that Indonesia went through at least three very different political regimes with different economic challenges in response to numerous domestic and global economic shocks in the 70 years under consideration. Nonetheless, while it may have been phrased a bit inconclusively, it appears that Booth generally admits that Indonesia has made significant progress, though some important problems remain and have been in place since the Dutch colonial era. Booth specifically allocates chapter 7 to 9 to address these problems of persistence. 
The first problem, discussed in chapter 7 , concerns the persistence of politically-connected businesses, which some commentators see as a second-best solution to market imperfection and others, especially after the 1998 crisis, as a major source of inefficiency in the economy. In fact, as the chapter shows, the government's attitude toward private businesses can be traced back to the unfinished debate between rationalist and nationalist camps since the early independence days. The reform on politically-connected firms and private sector liberalization, therefore, depends on which camps happened to have the administration's ear.

The second persistent problem, discussed in chapter 8 , refers to the longstanding popular sentiment of widespread poverty in the country, despite impressive economic growth and the official records reflecting a reduction in poverty and inequality. By discussing the statistical measurement problems at length, Booth seems to suggest that we indeed need to take those official numbers with a grain of salt. Such a measurement problem also, perhaps, justifies the popular sentiment of unfairness among Indonesians and poses serious challenges on the efficacy of redistribution policies claimed by various administrations throughout the years as achieved successes.

The third persistent problem is related to the development financing strategy, in other words, how to fund development projects and investment. In many ways, it is a result of unfinished debates among political elites on the preferred source of development financing: from the state, private sectors, or foreign investors. The stalling until recently of infrastructure development, as well as persistent problems in fiscal decentralization and budget efficiency reallocation, reflect such a lack of consensus on taxation and government expenditure strategies.

To conclude, for many economists trained in a more formal quantitative approach, this book might be seen as missing rigorous statistical empirical tests on whether exogenous shocks faced by Indonesia cause policy changes, or whether policy responses cause specific economic outcomes such as poverty reduction or growth. I would highlight, however, that this book displays a vast amount of insights in understanding the political economy of various major economic policies undertaken by the Indonesian government that could potentially motivate further research on the Indonesian economy with a more rigorous strategy of statistically identifying causality. This alone is no small feat.

\author{
Akhmad Rizal Shidiq \\ Leiden University \\ a.r.shidiq@hum.leidenuniv.nl
}

